\title{
Effect of Saussurea costus extracts in the viability of Echinococcus granulosus protoscoleces of sheep origin In vitro
}

\author{
Asmaa Fadhil Al-obaidy ${ }^{*}$, Fouad Salim Esmaeel ${ }^{2}$ \\ ${ }^{1 *, 2}$ Department of Biology, College of Education for Girls, University of Mosul, Mosul, Iraq \\ E-mail: ${ }^{1 *}$ mmsjy2971772@gmail.com,${ }^{2}$ falrubee@ uomosul.edu.iq
}

(Received May 16, 2021; Accepted June 27, 2021; Available online August 28, 2021)

DOI: 10.33899/edusj.2000.168656, () 2021, College of Education for Pure Science, University of Mosul.

This is an open access article under the CC BY 4.0 license (http://creativecommons.org/licenses/by/4.0/).

\begin{abstract}
Cystic echinococcosis is one of the most prevalence and dangerous zoonotic parasitic disease in the world. Iraq is one of the most countries that affected by this disease. Surgery is usually the most effective therapy and can be used with injection of drugs in hydatid cysts before surgery to kill protoscoleces to avoid anaphylactic shock as a result of spilling of hydatid cyst fluid into peritoneal cavity, as well as this reduce the chance of secondary hydatid cysts production. Therefore, the current study aimed to evaluate the effectiveness of Saussurea costus extracts on protoscoleces viability of Echinococcus granulosus, where the protoscoleces of E. granulosus exposed to four different concentrations of Saussurea costus extracts at four different exposure times including; 15, 30, 45 and $60 \mathrm{~min}$ in vitro, The results of ethanolic extract showed highest efficacy at concentration $20,30 \mathrm{mg} / \mathrm{ml}$ in $45,60 \mathrm{~min}$ and $40 \mathrm{mg} / \mathrm{ml}$ at all times. The highest scolicidal effect of petroleum ether extract was reported at 10 and $15 \mathrm{mg} / \mathrm{ml}$ during $60 \mathrm{~min}$, while $20 \mathrm{mg} / \mathrm{ml}$ reported similar effect at 45 and $60 \mathrm{~min}$. The data of cool aqueous extract showed reduction of protoscoleces viability to $0 \%$ at 200 and $250 \mathrm{mg} / \mathrm{ml}$ in 45 and $60 \mathrm{~min}$, respectively, while $300 \mathrm{mg} / \mathrm{ml}$ showed same reduction of viability at all experiment time periods. The data of hot aqueous extract showed $100 \%$ kill rate by using $350 \mathrm{mg} / \mathrm{ml}$ at $60 \mathrm{~min}$ and $400 \mathrm{mg} / \mathrm{ml}$ at 45 and 60 , as well as $450 \mathrm{mg} / \mathrm{ml}$ at all experiment period times. Comparing to the control group. Generally, Saussurea costus extracts have concentration and exposure time-dependent effect on protoscoleces viability.
\end{abstract}

Keyword: Echinococcus granulosus, Saussurea costus, protoscoleces

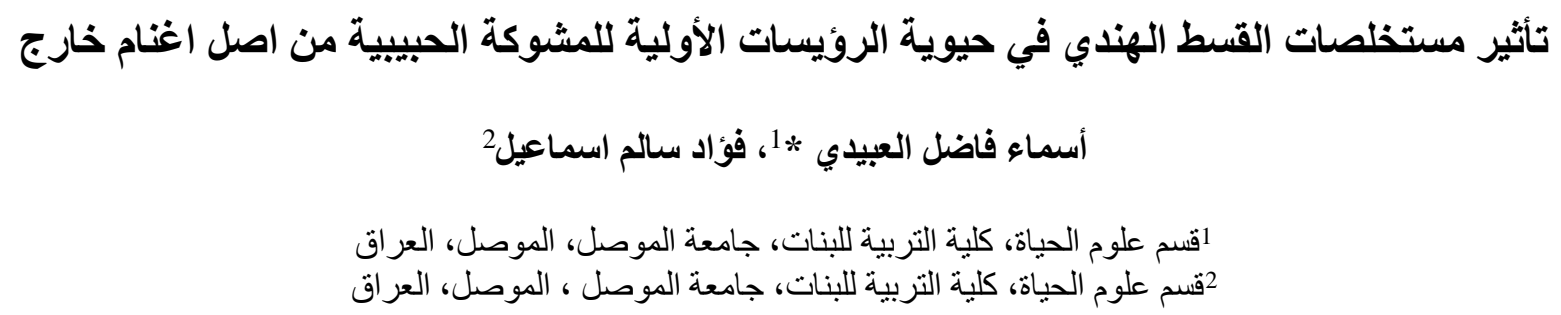


يعد داء المشوكات الكيسي من اكثر الامراض الطفيلية المشتركة بين الانسان والحيوان انتشاراً وخطورة في جميع انحاء العالم. ويعتبر العراق من الدول المتأثرة بهذا المرض .عادة ما تكون الجراحة هي العلاج الأكثر فعالية للمرض ويمكن استخدامها مع حقن الادوية في الاكياس العدرية قبل اجراء الجراحة لقتل الرؤيسات الأولية لتجنب حدوث الصدمة (التأقية) نتيجة أنتشار سائل الكيس العدري في التجويف البريتوني، بالإضافة الى ان هذا يقلل من فرصة تكون أكياس عدرية ثانوية. لذلك، هدفت الدراسة الحالية تقييم فعالية مستخلصات نبات Saussurea costus الأولية لطفيل المشوكة الحبيبية الى أربعة تراكيز مختلفة لمستخلصات نبات القسط الهندي خلال فترات تعرض وهي 15،30،45 و60 دقيقة خارج الجسم الحي. أظهرت نتائج المستخلص الايثانولي اعلى فاعلية له عند التركيز 20 و 30ملغم/مل في 45و60 دقيقة ،0ملغم/مل في جميع الأوقات. وكان اعلى تأثير قاتل لمستخلص بتروليوم أيثر عند التركيز 15و10ملغم/مل بعد 60 دقيقة و20ملغرام/مل بعد45 و 60 دقيقة وقد حقتت نتائج المستخلص المائي البارد انخفاض نسبة الحيوية الى 0\% عند تراكيز 200 و 250ملغم/مل في 45،60 دقيقة و300ملغم/مل في الأوقات15، 30، 45 و60دقيقة اما نتائج المستخلص المائي الحار فقد سجلت نسبة قتل 100\% عند تراكيز 350ملغم/مل في 60دقيقة و400ملغم/مل في 45و 60دقيقة و 450ملغ/مل في جميع الأوقات المستخدمة بالمقارنة مع مجموعة السيطرة. على العموم، فقد تتاسب تأثير مستخلصات القسط الهندي تناسباً طردياً مع زيادة التركيز وزيادة مدة التعريض. الكلمات المفتاحية: المشوكة الحبيبية، القسط الهندي، الرؤيسات الأولية

\section{Introduction}

Echinococcosis or Hydatidosis is a zoonotic disease, caused by the metacestode or larval stage of a dog tapeworm Echinococcus granulosus [1,2]. E. granulosus spread in central Asia, China, North and East Africa, Australia and South America [3] . Life cycle of E. granulosus in definitive host, represented by the canids which harbors the adult worms in their intestines, and intermediate host includes livestock, as well as human which act as an accidental host. The intermediated host can be infected by orally ingestion of parasite eggs which develop into fluid-filled cysts in their liver, lungs, and other organs [4]. The disease causes expanded mortality and morbidity in human and livestock [5]. Echinococcosis disease is asymptomatic for several years, and the clinical symptoms can appear due to increase of cyst size which cause pressure on nearby tissues [6].

There are several methods of treatment echinococcosis including surgery, percutaneous technique, chemotherapy [7]. Surgery is the most effective therapy of the disease but with quite difficult for some cases because the cyst diffusion in to many organs or formed in risky location [8]. Chemotherapy by singing benzimidazole derivatives are necessary in cases of possible recurrence, injury to several organs in the body and addition to cases of the advanced stages [9]. However, it has side effects such as nausea, vomiting, diarrhea, abdominal pain, headache, it may cause gastro-intestinal and liver functions disturbances, hematuria and leukopenia [10]. In order to reduce the risk of hydatid fluid spillage of the cysts during surgery and to prevent reoccurrence of echinococcosis, which may occur in approximately $10 \%$ of postoperative cases[11]. Therefore, the use of more effective and less harmful agents to treat this disease is important [12], such as pistacia vera, zataria multiflora and other plants [13,14]. 
Saussurea costus belongs to family of Asteraceae is one of the main species of the genus Saussurea [15] which mostly grow in the humid regions at altitude of 2600-4000m in Western Himalayan region of India and Pakistan, and it is also been started to cultivate in new areas for commercial purposes in 1920 [16]. The roots of S. costus are used for the treatment many diseases including chronic gastritis, stomach ulcer, asthma, bronchitis and rheumatoid [17], oil extracts from the roots of S. costus has been used in the treatment of leprosy [18]. Chemical studies of the S. costus plant have shown it contains many phytochemical compounds with biological activity, including alkaloids, flavonoids, sesquiterpene terpenes, anthraquiones and tannins [19,20].

This study aims to determinate the effect of $S$.costus extracts on viability of E. granulosus protoscoleces In vitro.

\section{Materials and methods}

\section{Samples collection and protoscoleces isolation:}

The infected livers of sheep (figure1) were collected from butcher shops in Mosul city and protoscoleces of E. granulosus were isolated according to Smyth [21] by sterilizing the surface of hydatid cyst with 70\% ethanol following by aspiration of hydatid cyst fluid using G21 needle. Protoscoleces were washed three times with phosphate buffered saline (PBS) using centrifuge at 3000rpm for 10minutes, with the addition of $1 \mathrm{gm}$ of streptomycin and $20000 \mathrm{UI}$ of penicillin before starting a second wash.

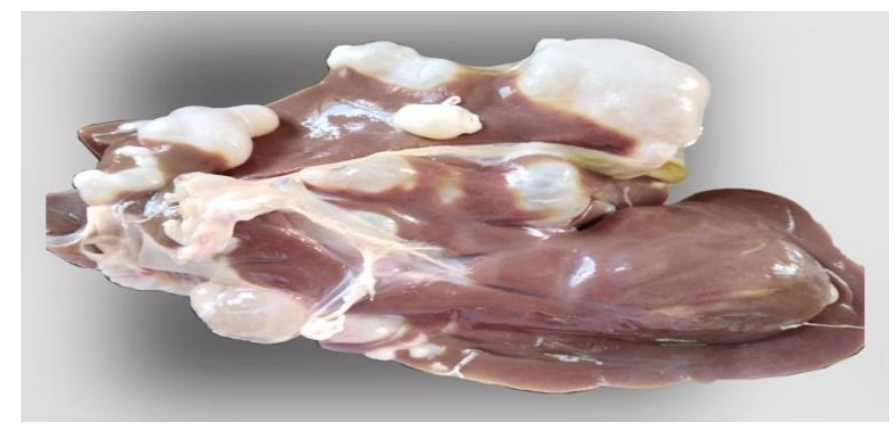

Figure1: Hydatid cysts in the liver of sheep

\section{Estimation of protoscoleces viability:}

The assessment of the viability of protoscoleces was estimated by taking $20 \mathrm{ul}$ of the hanging of protoscoleces was mixed with $20 \mathrm{ul}$ of $0.1 \%$ eosin stain on the glass slide. Protoscoleces that appear by bright green in color considered alive ( figure 2) while protoscoleces red in color dead because stain entry inside it (figure 3) [22].The viability of the protoscoleces in this study was $100 \%$. 


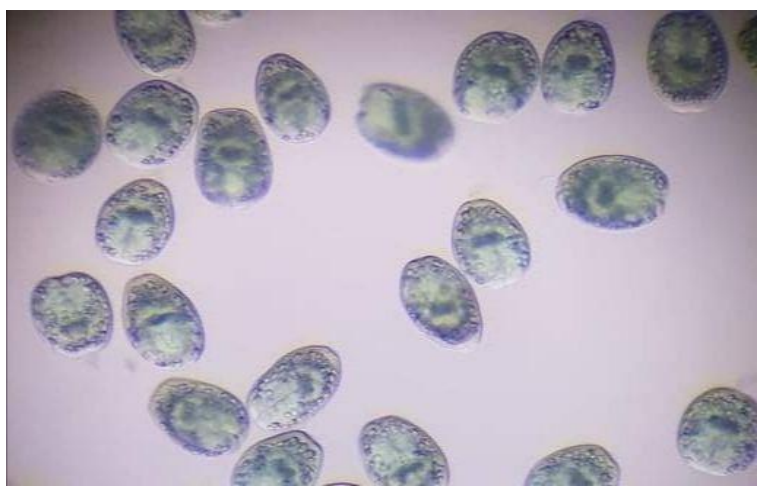

Figure 2 : Live protoscoleces before treated with extracts after dye it with $0.1 \%$ eosin

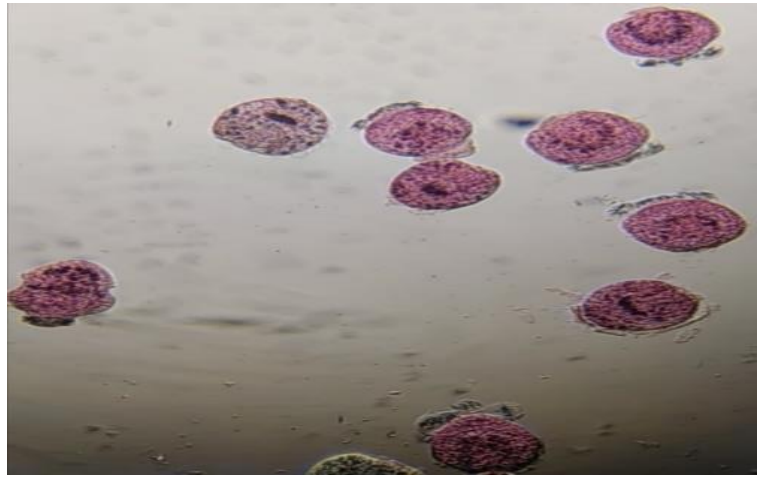

Figure 3 : Dead protoscoleces after treated with extract and dye it with $0.1 \%$ eosin

\section{Collection and preparation of the $S$. costus extracts}

S. costus plant was bought from perfumery shops in Mosul city. $25 \mathrm{gm}$ from a root of plant powder were added to $500 \mathrm{ml}$ of petroleum ether for 72 hours on magnetic stirrer, then solution were filtered by Whatman No.1 filter paper, $500 \mathrm{ml}$ Ethanol $70 \%$ is added to the precipitant for 72 hours on magnetic stirrer [23], after filtering the solution, distilled water was added to precipitant on magnetic stirrer at medium speed and temperature $60 \mathrm{C}^{\circ}$ to obtain a warm water extract, The solvent was removed by using rotary evaporator at $40 \mathrm{C}^{\circ}$ [24] . Cool aqueous extract was prepared according to Rios et al. method [25], where $40 \mathrm{~g}$ of root plant powder was added to $400 \mathrm{ml}$ of distilled water following by mixing process using blender and then magnetic stirrer. The samples underwent to soak and mix for 24 hours at $4 \mathrm{C}^{\circ}$. The samples were filtered using Whatman filter paper No.1 following by store the crude extracts at $4 \mathrm{C}^{\circ}$, until been used.

\section{Effect of $S$. costus extracts on protoscoleces viability In vitro}

To evaluate the effect extracts on viability of the protoscoleces, experiments were designed that included four different concentrations at four different times, in addition to the control group. In each test tube $1 \mathrm{ml}$ of extract dissolved in PBS was added, with the addition of 2000 protoscoleces in the same tube and placed in a water bath at $37 \mathrm{C}$. according to the specified times washed with PBS solution to get rid of the effect of extracts and examined protoscoleces under a light microscope to count the living and dead ones.

\section{Statistical analysis}

Data analysis was carried out using the SPSS statistical analysis system, the means and standard error were used, in addition to using Duncon's test to measure a significant difference between the means of experimental study at the level of significance $\mathrm{p} \leq 0.05$.

\section{Results and Discussion}

The results of this study showed the effect of petroleum ether extract $S$. costus on protoscoleces viability in vitro using four concentrations $5,10,15$ and $20 \mathrm{mg} / \mathrm{ml}$ at four different times 15,30,45 and 
60 minutes. The data of petroleum ether extract indicated $0 \%$ of viability rate at $10 \mathrm{mg} / \mathrm{ml} \mathrm{and} 15 \mathrm{mg} / \mathrm{ml}$ during $60 \mathrm{~min}$, while $20 \mathrm{mg} / \mathrm{ml}$ indicated $0 \%$ of viability at 45 and $60 \mathrm{~min}$. The highest percentage of viability $(47.785 \%)$ reported at $5 \mathrm{mg} / \mathrm{ml}$ during $15 \mathrm{~min}$ (see table-1).

Table 1. The effect of petroleum ether extract of S. costus on viability percentage of protoscoleces.

\begin{tabular}{|c|c|c|c|c|c|}
\hline \multirow[b]{2}{*}{ Con. } & Control & \multicolumn{4}{|c|}{ Viability of protoscoleces (\%) at different time } \\
\hline & \multirow{5}{*}{100} & $15 \mathrm{~min}$. & $30 \mathrm{~min}$. & $45 \mathrm{~min}$. & $60 \mathrm{~min}$. \\
\hline $5 \mathrm{mg}$ & & $\begin{array}{c}47.785 \pm 1.278 \\
\mathrm{f}\end{array}$ & $\begin{array}{c}25.850 \pm 2.626 \\
\mathrm{e}\end{array}$ & $\begin{array}{c}19.440 \pm 0.329 \\
\mathrm{~d}\end{array}$ & $\begin{array}{c}2.500 \pm 1.443 \\
\mathrm{a}\end{array}$ \\
\hline $10 \mathrm{mg}$ & & $\begin{array}{c}42.565 \pm 1.405 \\
\mathrm{e}\end{array}$ & $\begin{array}{c}18.220 \pm 0.408 \\
\mathrm{~d}\end{array}$ & $\begin{array}{c}13.330 \pm 0.408 \\
\mathrm{c}\end{array}$ & $\begin{array}{l}0 \\
\mathrm{a}\end{array}$ \\
\hline $15 \mathrm{mg}$ & & $\begin{array}{c}17.140 \pm 0.790 \\
\mathrm{~d}\end{array}$ & $\begin{array}{c}9.830 \pm 1.056 \\
\mathrm{~b}\end{array}$ & $\begin{array}{c}1.495 \pm 0.863 \\
\mathrm{a} \\
\end{array}$ & $\begin{array}{l}0 \\
\mathrm{a}\end{array}$ \\
\hline $20 \mathrm{mg}$ & & $\begin{array}{c}10.800 \pm 0.408 \\
\text { bc }\end{array}$ & $\begin{array}{c}1.515 \pm 0.874 \\
\mathrm{a}\end{array}$ & $\begin{array}{l}0 \\
\mathrm{a}\end{array}$ & $\begin{array}{l}0 \\
\mathrm{a}\end{array}$ \\
\hline
\end{tabular}

Similar letters in the table above indicate there are no significant differences between values at $\mathrm{p} \leq 0.05$, while different letters indicate there are significant differences between values at $\mathrm{p} \leq 0.05$.

The current study results showed the effect of Ethanolic extract S. costus on protoscoleces viability In vitro using four concentrations 10,20,30 and $40 \mathrm{mg} / \mathrm{ml}$ at four different times 15,30,45 and 60 minutes. Lowest percentage of viability rate reported at $20 \mathrm{mg} / \mathrm{ml}$ and $30 \mathrm{mg} / \mathrm{ml}$ during 45 and $60 \mathrm{~min}$, while $40 \mathrm{mg} / \mathrm{ml}$ indicated lowest viability percentage $(0 \%)$ at all experimental time periods. The highest viability percentage $(100 \%)$ was reported at $10 \mathrm{mg} / \mathrm{ml}$ during $15 \mathrm{~min}$. (see table-2).

Table 2 . The effect of ethanolic extract of S. costus on viability percentage of protoscoleces.

\begin{tabular}{|c|c|c|c|c|c|}
\hline \multirow{2}{*}{ Con. } & Control & \multicolumn{3}{|c|}{ Viability of protoscoleces (\%) at different times } \\
\cline { 4 - 6 } & & $15 \mathrm{~min}$ & $30 \mathrm{~min}$ & $45 \mathrm{~min}$ & $60 \mathrm{~min}$ \\
\cline { 4 - 6 } $10 \mathrm{mg}$ & & $100.000 \pm 0.000 \mathrm{~g}$ & $69.7900 \pm 3.181 \mathrm{f}$ & $28.570 \pm 0.408 \mathrm{e}$ & $23.640 \pm 0.871 \mathrm{~d}$ \\
\cline { 4 - 6 } & \multirow{3}{*}{100} & $27.470 \pm 1.749 \mathrm{e}$ & $18.570 \pm 0.825 \mathrm{c}$ & $0 \mathrm{a}$ & $0 \mathrm{a}$ \\
\cline { 4 - 6 } & & $7.566 \pm 1.261 \mathrm{~b}$ & $1.110 \pm 0.702 \mathrm{a}$ & $0 \mathrm{a}$ & $0 \mathrm{a}$ \\
\cline { 4 - 6 } & & $0 \mathrm{a}$ & $0 \mathrm{a}$ & $0 \mathrm{a}$ & $0 \mathrm{a}$ \\
\cline { 4 - 5 } & & & & & 0 \\
\hline
\end{tabular}

Similar letters in the table above indicate there are no significant differences between values at $\mathrm{p} \leq 0.05$, while different letters indicate there are significant differences between values at $\mathrm{p} \leq 0.05$. 
The current data showed the effect of hot aquatic extract of $S$. costus on protoscoleces viability in vitro using four concentrations $300,350,400$ and $450 \mathrm{mg} / \mathrm{ml}$ at four different times 15,30,45 and 60min Lowest percentage of vitality rate $(0 \%)$ Showed at $350 \mathrm{mg} / \mathrm{ml}$ and $400 \mathrm{mg} / \mathrm{ml}$ during 60 and $45 \mathrm{~min}$, respectively, while $450 \mathrm{mg} / \mathrm{ml}$ indicated lowest viability percentage $(0 \%)$ at all experimental time periods. The highest viability percentage $(52.165 \%$ ) was reported at $300 \mathrm{mg} / \mathrm{ml}$ during $15 \mathrm{~min}$. (see table-3).

Table 3 . The effect of hot aquatic extract of $S$. costus on viability percentage of protoscoleces.

\begin{tabular}{|c|c|c|c|c|c|}
\hline \multirow[b]{2}{*}{$\begin{array}{l}\text { Con. } \\
\mathrm{mg} / \mathrm{ml}\end{array}$} & \multicolumn{5}{|c|}{ Viability of protoscoleces $(\%)$ at different times } \\
\hline & Control & $15 \mathrm{~min}$ & $30 \mathrm{~min}$ & $45 \mathrm{~min}$ & $60 \mathrm{~min}$ \\
\hline $300 \mathrm{mg}$ & & $\begin{array}{c}52.165 \pm 3.559 \\
f\end{array}$ & $\begin{array}{c}39.950 \pm 0.871 \\
\mathrm{e}\end{array}$ & $\begin{array}{c}24.162 \pm 3.314 \\
c\end{array}$ & $\begin{array}{c}2.940 \pm 1.697 \\
\mathrm{a}\end{array}$ \\
\hline $350 \mathrm{mg}$ & 100 & $\begin{array}{c}30.337 \pm 1.998 \\
\mathrm{~d}\end{array}$ & $\begin{array}{c}22.525 \pm 0.574 \\
c\end{array}$ & $\begin{array}{c}1.095 \pm 0.632 \\
\mathrm{a}\end{array}$ & $\begin{array}{l}0 \\
\mathrm{a}\end{array}$ \\
\hline $400 \mathrm{mg}$ & & $\begin{array}{c}24.215 \pm 1.425 \\
c\end{array}$ & $\begin{array}{c}11.425 \pm 3.299 \\
b\end{array}$ & $\begin{array}{l}0 \\
\mathrm{a}\end{array}$ & $\begin{array}{l}0 \\
\mathrm{a}\end{array}$ \\
\hline $450 \mathrm{mg}$ & & $\begin{array}{l}0 \\
\mathrm{a}\end{array}$ & $\begin{array}{l}0 \\
\mathrm{a}\end{array}$ & $\begin{array}{l}0 \\
\mathrm{a}\end{array}$ & $\begin{array}{l}0 \\
\mathrm{a}\end{array}$ \\
\hline
\end{tabular}

Similar letters in the table above indicate there are no significant differences between values at $\mathrm{p} \leq 0.05$, while different letters indicate there are significant differences between values at $\mathrm{p} \leq 0.05$.

The data of cool aqueous extract of $S$. costus on protoscoleces viability in vitro using four concentrations $150,200,250$ and $300, \mathrm{mg} / \mathrm{ml}$ at four different times $15,30,45$ and 60 minutes. Indicated lowest viability percentage $(0 \%)$ at $200 \mathrm{mg} / \mathrm{ml}$ during 45 and $60 \mathrm{~min}$, while $250 \mathrm{mg} / \mathrm{ml}$ showed $0 \%$ of viability at 30,45 and $60 \mathrm{~min}$, in addition to $300 \mathrm{mg} / \mathrm{ml}$ showed $0 \%$ of viability during all experimental time periods (see table-4). 
Table 4 . The effect of cool aquatic extract of $S$. costus on viability percentage of protoscoleces.

\begin{tabular}{|c|c|c|c|c|c|}
\hline \multirow[b]{2}{*}{$\begin{array}{l}\text { Con. } \\
\mathrm{mg} / \mathrm{ml}\end{array}$} & \multicolumn{5}{|c|}{ Viability of protoscoleces $(\%)$ at different times } \\
\hline & Control & $15 \mathrm{~min}$ & 30min & $45 \mathrm{~min}$ & $60 \mathrm{~min}$ \\
\hline $150 \mathrm{mg}$ & \multirow{4}{*}{100} & $\begin{array}{c}48.680 \pm 1.166 \\
\mathrm{~d}\end{array}$ & $\begin{array}{c}31.700 \pm 2.136 \\
\mathrm{c}\end{array}$ & $\begin{array}{c}9.530 \pm 0.779 \\
b\end{array}$ & $\begin{array}{c}2.470 \pm 0.867 \\
\mathrm{a}\end{array}$ \\
\hline $200 \mathrm{mg}$ & & $\begin{array}{c}31.245 \pm 1.244 \\
\mathrm{c}\end{array}$ & $\begin{array}{c}2.732 \pm 1.034 \\
\mathrm{a}\end{array}$ & $\begin{array}{l}0 \\
\mathrm{a}\end{array}$ & $\begin{array}{l}0 \\
\mathrm{a}\end{array}$ \\
\hline $250 \mathrm{mg}$ & & $\begin{array}{c}2.652 \pm 1.885 \\
\mathrm{a}\end{array}$ & $\begin{array}{l}0 \\
\mathrm{a}\end{array}$ & $\begin{array}{l}0 \\
\mathrm{a}\end{array}$ & $\begin{array}{l}0 \\
\mathrm{a}\end{array}$ \\
\hline $300 \mathrm{mg}$ & & $\begin{array}{l}0 \\
\mathrm{a}\end{array}$ & $\begin{array}{l}0 \\
\mathrm{a}\end{array}$ & $\begin{array}{l}0 \\
\mathrm{a}\end{array}$ & $\begin{array}{l}0 \\
\mathrm{a}\end{array}$ \\
\hline
\end{tabular}

Similar letters in the table above indicate there are no significant differences between values at $p \leq 0.05$, while different letters indicate there are significant differences between values at $\mathrm{p} \leq 0.05$.

The viability rate of protoscoleces for petroleum ether extract decreased to zero at concentration 10 and $15 \mathrm{mg} / \mathrm{ml}$ after $60 \mathrm{~min}$ and $20 \mathrm{mg} / \mathrm{ml}$ after exposure time of $45 \mathrm{and} 60 \mathrm{~min}$, results are converged with a study of El-Bahy et al. [28] that achieved the maximum mortality rate among the protoscoleces $100 \%$ when used Nigella sativa oil at $100 \mathrm{mg} / \mathrm{ml}$ concentration after $120 \mathrm{~min}$ with the superiority of a current study in time and focus. The current study also outperformed in terms of achieving a high killing rate compared to the results of Hesari et al. [29] study, where they reported highest mortality rate $4 \%$ when used petroleum ether extract of Cucurbita moshata at concentration $10 \mathrm{mg} / \mathrm{ml}$ in $60 \mathrm{~min}$.

The present study showed that S.costus extracts inhibitive efficiency against protoscoleces of $E$. granulosus to different concentration at times different. The current data of ethanolic extract indicated $100 \%$ kill rate at 20 and $30 \mathrm{mg} / \mathrm{ml}$ during 45 and $60 \mathrm{~min}$, while the same kill rate was reported at $40 \mathrm{mg} / \mathrm{ml}$ during all experiment time periods. This data is in an agreement with the data that obtained by previous study [26], where they reported $100 \%$ kill rate by using $50 \mathrm{mg} / \mathrm{ml}$ of ethanolic extract of Salvadora persica at $20 \mathrm{~min}$. These results were superior in terms of concentration, time and killing rate on results Al-Aloosi et al. [27] when used alcoholic extract of viscum album showed high killing (80.7\%) at 1500mg/ml in60 $\min$.

The concentration $450 \mathrm{mg} / \mathrm{ml}$ of hot aqueous extract showed highest kill rate $(100 \%)$ at all experiment time periods. These results are in an agreement with previous data [30], where he reported reduction of protoscoleces viability from $87 \%$ to $0 \%$ by fourth day of experiment by using hot aqueous extract of ziziphus spina. 
Regarding to the current data of cool aqueous extract, $100 \%$ kill rate was reported at $250 \mathrm{mg} / \mathrm{ml}$ at 15 , 30 and $45 \mathrm{~min}$, while $300 \mathrm{mg} / \mathrm{ml}$ reported same kill rate during all experiment time periods. These results are agreed with the data obtained previously [31], where cool aqueous extract of Citrus aurantifolia reported $100 \%$ kill rate at $15,20,50$ and $100 \mathrm{mg} / \mathrm{ml}$ after 24,48 and 96 hours.

The scolicidal effect of these extracts may be attributed to the medicinal properties of the roots $S$. costus plant Including antimicrobial, anti- inflammatory, anticancer, analgesic and heptoprotective properties in humans[18]. In addition to the death of protoscoleces determined by entering eosin dye inside parasite which caused some structural changes including distribution of hooklets in protoscoleces cytoplasm and membranous swellings of protoscoleces plasma membrane in some cases.

\section{Conclusion}

It is concluded that all extracts of $S$. costus have scolicidal effect on E. granulosus protoscoleces which represented by concentration and exposure time-dependent effects.

\section{References}

1. A. Hizem, S. Oudni- M'rad, M. Mezhoud, H. Ben Jannet, G. Flamini, K. Ghedira, and H. Babba, Journal of Essential Oil Research, vol.32,no.2, pp.178-185, 2020, https://doi.org/10.1080/10412905.2019.1711212.

2. A. Casulli, The Lancet Global Health, vol. 8, no.4, pp.e470-e471,2020.

3. P. Deplazes, L. Rinaldi, C.A. Rojas, P.R. Torgerson, M.F. Harandi,T. Romig, D. Antolova, JM. Schurer, S. Lahmar, G. Cringoli, and J. Magambo, vol.95, pp.315-493, 2017, https://doi.org/10.1016/bs.apar.2016.11.001.

4. T. Romig, P. Deplazes, D. Jenkins, P. Giraudoux, A. Massolo, P.S. Craig, M. Wassermann, K. Takahashi, and M. De La Rue,Advances in parasitology, Vol. 95, pp.213-314, 2017, https://doi.org/10.1016/bs.apar.2016.11.002

5. S.Y. Yousif, A.A Ali, Iraqi J Vet Sci. vol. 34, no.1,pp.115-121, 2020, Doi: 10.33899/ijvs.2019.125613.1104 .

6. G. Dvorak, A. Rovid-spickler, \& J. A. Roth, Center for Food Security and Puplic Health," pp. 120-121, 2008.

7. H. Wen, L. Vuitton, T.Li.j. Tuxun, D.A Vuitton, W. Zhang, \&D.P McManus, Clinical microbiology reviews, vol.32, no.2,pp. e00075-18, 2019, DOI: 10.1128/CMR.00075-18.

8. R. Norouzi, A. Ataei, M. Hejazy, A. Noreddin, \& M.E. El Zowalaty, International journal of nanomedicine" vol. 15, pp.1095-1100,2020.

9. L.M. Wen, G.D Lü, J. Zhao, S. Lu, H.J. Gao, B. Chen, Y.F. Ma, Y.F. Xiao, Y. Yuan, H.B. Zhang, and H. Liu, The Journal of parasitology, vol.103, no.6, pp.699-707, 2017, https://doi.org/10.1645/16-164 
10. A. Hemphill, B. Stadelmann, R. Rufener, M. Spiliotis, G. Boubaker, J. Müller, N. Müller, D. Gorgas, and B. Gottstein, Parasite, vol. 21, no. 70, pp.1-26, 2014.

11. E. Brunetti, P. Kern, and D.A,Vuitton, Acta tropica,vol. 114,no1, pp.1-16, 2010, https://doi.org/10.1016/j.actatropica.2009.11.001 .

12. S.M. Sadjjadi, M.R. Zoharizadeh, and M.R. Panjeshahin, Journal of Investigative Surgery, vol, 21no.6, pp.318-322, 2008, https://doi.org/10.1080/08941930802348261

13. H. Mahmoudvand, F. Kheirandish, E.S. Dezaki, S. Shamsaddini, and M.F. Harandi, Biomedicine \& Pharmacotherapy, vol.82, pp.393-398, 2016, https://doi.org/10.1016/j.biopha.2016.05.012

14. H. Mahmoudvand, S.R. Mirbadie, S. Sadooghian, M.F. Harandi, S. Jahanbakhsh, and E. Saedi Dezaki, Journal of EssEntial oil rEsEarch, vol, 29,no.1, pp.42-47, 2017, https://doi.org/10.1080/10412905.2016.1201546

15. K. Zahara, S. Tabassum, S. Sabir, M. Arshad, R. Qureshi, M.S Amjad, and S,K.Chaudhari, Asian Pacific journal of tropical medicine, vol.7, pp.S60-S69, 2014, https://doi.org/10.1016/S19957645(14)60204-2.

16. S. Ansari, Pharmacognosy Reviews, vol. 13, no.26, p.71,2019.

17. S.L. Chen, H. Yu, H.M. Luo, Q. Wu, C.F. Li, A. and Steinmetz, Chinese medicine, vol.11, no.1, pp.110,2016 .

18. A.H. Al-Adhroey, Y.M. Al-Abhar, N.M. Noman, and H.M.Al-Mekhlafi, Journal of Herbal Medicine, vol.21, p.100332, 2020, https://doi.org/10.1016/i.hermed.2020.100332.

19. N. Ebadi, S. Bagheri, A. Manayi, T. Toliyat, S Sadrai, M. Tabarrai, and Z. Niktabe, Research Journal of Pharmacognosy, vol. 5no.4, pp.25-32, 2018,doi 10.22127/RJP.2018.69214

20. R. Hassan, and M.H. Masoodi, Current Traditional Medicine, vol.6, no.1, pp.13-23, 2020,

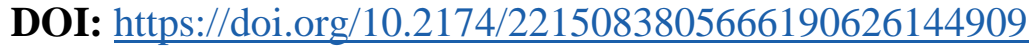

21. J. D. Smyth, Madrid, PP. 84-89, 1985.

22. J.D. Smyth, \& N.J. Barrett, Transactions of the Royal Society of Tropical Medicine and Hygiene, vol. 74, no.5, pp. 649-652, 1980, Doi: 10.1016/0035-9203(80)90157-1.

23. A. Le Grand, P.A. Wondergem, R. Verpoorte, and JL. Pousset, Journal of ethnopharmacology, vol. 22, no. 1, pp.25-31, 1988, https://doi.org/10.1016/0378-8741(87)90122-X

24. J.B. Harborne, In Phytochemical methods, pp. 1-36, Springer, Dordrecht, 1984.

25. J.L. Rios, M.C. Recio, and A. Villar, Journal of ethnopharmacology, vol. 21, no. 2, pp.139-152, 1987, https://doi.org/10.1016/0378-8741(87)90124-3. 
26. A.A.S. Abdel-Baki, E. Almalki, L. Mansour, and S. Al-Quarishy, The Korean journal of parasitology, vol. 54,no.1, p.64,2016.

27. T.T. Al-Aloosi, A.A. Al-Tai, and A.M. Al-Samarrai, Tikrit Journal of Pure Science, vol. 22 no.9, pp.16-19, 2018.

28. N.M. El-Bahy, A.R. Abdelaziz, and R.F. Khalafalla, Revista Brasileira de Parasitologia Veterinária, vol. 28, no. 2, pp.210-214, 2019, https://doi.org/10.1590/S1984-29612019019

29. Z. Hesari, M. Sharifdini, M.K. Sharifi-Yazdi, S. Ghafari, S. Ghasemi, S. Mahmoudi, M. Mohebali, and B. Nikmanesh, Iranian Journal of Parasitology, vol. 15 no.1, p.82,2020.

30. S.A. Al-Musawi, kufa Journal for Nursing sciences, vol. 4,no.3, 2014.

31. M.H.F, Al-Kurayshi, AL-Qadisiyah Journal of pure Science, vol.23, no.3, pp.76-86, 2018, DOI: https://doi.org/10.29350/jops.2018.23.3.893. 